\begin{tabular}{|c|c|c|c|c|c|}
\hline JRL & Vol. 12 & No.2 & Hal : 99-106 & $\begin{array}{c}\text { Jakarta, } \\
\text { Desember 2019 }\end{array}$ & $\begin{array}{c}\text { p-ISSN : 2085.38616 } \\
\text { e-ISSN : 2580-0442 }\end{array}$ \\
\hline
\end{tabular}

\title{
UI KAPASITAS ABSORPSI AIR OLEH SELULOSA DARI TANDAN SAWIT SEBAGAI BAHAN SUPER ABSORBENT POLYMER (SAP) PADA POPOK SEKALI PAKAI
}

\author{
DIAN PURWITASARI DEWANTI, ANIES MA'RUFATIN, DAN RUDI NUGROHO \\ Pusat Teknologi Lingkungan, BPPT \\ Gedung 820 Geostech, Kawasan PUSPIPTEK, Serpong, Tangerang Selatan \\ Email : dianpurwitasaridewanti@gmail.com
}

\begin{abstract}
ABSTRAK
Selulosa tandan kosong kelapa sawit merupakan bahan yang potensial untuk dijadikan produk lain yang bernilai yang salah satunya adalah super absorbent polymer (SAP). Keunggulannya dibandingkan dengan selulosa sintetik karena mudah didapat dan mudah terurai secara alami oleh lingkungan. Penggunaan selulosa sebagai bahan SAP diarahkan untuk diaplikasikan pada popok sekali pakai. Hal ini karena permintaan terhadap popok sekali pakai sudah sangat besar dan menimbulkan permasalahan lingkungan karena limbah habis pakainya. Sehingga, tujuan penelitian ini adalah menguji kemampuan penyerapan air oleh selulosa dan dibandingkan dengan SAP yang sudah diaplikasikan pada popok sekali pakai. Bahan yang digunakan dalam penelitian ini adalah selulosa yang diekstraksi dari tandan kosong kelapa sawit dan serat dalam popok sekali pakai. Ekstraksi dilakukan dengan proses pemurnian dalam larutan $\mathrm{NaOH}$ dan dilanjutkan dengan pemutihan menggunakan $\mathrm{H}_{2} \mathrm{O}_{2}$. Selulosa kering yang didapat selanjutnya diuji penyerapannya terhadap air. SAP dalam popok sekali pakai juga mengalami perlakuan sama untuk mengetahui kemampuan penyerapannya. Dari hasil pengujian, didapatkan bahwa selama 4 jam, selulosa mampu menyerap air sebanyak 7 kali berat selulosa awal. Sedangkan untuk SAP memiliki kemampuan penyerapan hingga 200 kali berat asal. Diharapkan dipenelitian berikutnya bisa dilakukan proses polimerisasi selulosa menjadi SAP sehingga bisa menggantikan SAP sintesis.
\end{abstract}

Kata kunci : SAP, selulosa, popok sekali pakai, tandan kelapa sawit, polimerisasi 


\title{
WATER ABSORPTION CAPACITY TEST OF CELLULOSE FROM AOIL PALM BUNCHES AS MATERIAL FOR SUPER ABSORBENT POLYMER (SAP) IN DISPOSABLE DIAPERS
}

\begin{abstract}
Oil palm empty fruit bunches cellulose is a potential material to be used as another valuable product, one of which is a super absorbent polymer (SAP). The advantage compared to synthetic cellulose is that it is easy to obtain and easily decomposes naturally by the environment. The use of cellulose as SAP material is directed to be applied to disposable diapers. This is because the demand for disposable diapers is already very large and causes environmental problems because the waste is used up. Thus, the purpose of this study is to test the ability of water absorption by cellulose and compared with SAP which has been applied to disposable diapers. The material used in this study was cellulose extracted from oil palm empty fruit bunches and fiber in disposable diapers. Extraction is done by purification process in $\mathrm{NaOH}$ solution and followed by bleaching using $\mathrm{H}_{2} \mathrm{O}_{2}$. The dry cellulose obtained was then tested for its absorption in water. SAP in disposables also experiences the same treatment to determine its absorption ability. From the results of the test, it was stated that for 4 hours, cellulose was able to absorb 7 times the weight of the initial cellulose. Whereas SAP has the ability to absorb up to 200 times the original weight. It is hoped that in the next research cellulose polymerization process can be carried out into SAP so that it can replace SAP synthesis.
\end{abstract}

Keyword : cellulose, SAP, disposable diapers, empty fruit bunches, polimerization 


\section{PENDAHULUAN}

\subsection{Latar Belakang}

Jumlah kelahiran bayi yang mencapai 10.000 orang per hari di Indonesia menyebabkan peningkatan permintaan terhadap popok sekali pakai. Pemilihan popok sekali pakai dianggap lebih praktis dan tidak merepotkan. Hal ini karena popok mampu menyerap urin bayi sampai volume tertentu dengan adanya material polimer yang dikenal sebagai Super Absorbent Polimer (SAP). Selain itu, popok sekali pakai bisa langsung dibuang tanpa harus dicuci dan dikeringkan. Meningkatnya kebutuhan popok sekali pakai tersebut menyebabkan peningkatan kebutuhan SAP. SAP merupakan polimer sintetis yang berbasis minyak bumi.

SAP dalam popok sekali pakai berperan penting dalam menyerap urin bayi atau cairan dari tinja sampai volume tertentu sehingga bayi lebih nyaman untuk beberapa waktu. Apabila SAP sudah pada batas maksimalnya menyerap cairan, maka popok sekali pakai tersebut biasa langsung dilepas lalu dibuang dan selanjutnya diganti dengan popok yang baru. Satu gram SAP pada popok sekali pakai (pospak) mampu menyerap 20 - $40 \mathrm{ml}$ urin.

Saat ini, popok sekali pakai merupakan limbah terbanyak yang ditemukan dilingkungan setelah plastik. Kandungan bahan SAP yang diproduksi saat ini merupakan bahan polimer sintetis yang berbasis minyak bumi dan sulit terdegradasi oleh lingkungan. Cairan yang terserap dan kotoran yang ada menjadi bahan yang infeksius dan perlu mendapatkan perhatian khusus. Hal ini akan menjadi masalah kesehatan ketika sampah popok sekali pakai tersebut menumpuk dan tidak terurai. Oleh karena itu, pengembangan popok sekali pakai yang menggunakan SAP yang bisa terurai oleh lingkungan sangat mendesak untuk dilakukan.

SAP sebenarnya bisa diproduksi dari bahan yang berbasis polimer alam yang lebih ramah lingkungan. SAP dapat diproduksi dari polimer karbohidrat yang lebih murah, jumlahnya tersedia banyak, material yang bisa diperbaharui, dan mudah terdegradasi oleh lingkungan ${ }^{(1)}$.

Salah satu bahan yang potensial untuk dijadikan bahan baku SAP adalah polimer alat yang disebut selulosa yang terkandung dalam Tandan Kosong Kelapa Sawit (TKKS).

Berdasarkan data BPS tahun 2015, Indonesia memiliki luas perkebunan kelapa sawit sebesar 6.735.300 hektar yang tersebar di 22 propinsi dengan produksi tandan buah segar (TBS) kelapa sawit sebesar 31.070.000 ton per tahun. Sebanyak 25-26\% dari total produksi TBS kelapa sawit tersebut merupakan tandan kosong yang menjadi produk samping. Baru sebanyak 10\% dari TKKS tersebut yang sudah dimanfaatkan untuk bahan bakar boiler maupun kompos, dan sisanya masih menjadi limbah.

Selulosa TKKS bisa didapatkan dengan memurnikannya dari pengotor lain seperti hemiselulosa dan lignin dalam proses basa dan diputihkan dengan pemanasan dalam larutan hydrogen peroksida.

Untuk mengetahui potensi selulosa sebagai bahan baku SAP maka perlu dilakukan pengujian absorpsi terhadap $\mathrm{H}_{2} \mathrm{O}$. 


\subsection{Tujuan Penelitian}

Penelitian ini bertujuan mengetahui kemampuan selulosa dari tandan kosong kelapa sawit untuk menyerap air dan dibandingkan dengan bahan penyerap pada popok sekali pakai.

\section{BAHAN DAN METODE}

\subsection{Bahan}

Bahan yang digunakan adalah selulosa hasil ekstraksi dari tandan kosong kelapa sawit yang sudah kering. Akuades digunakan untuk menguji kemampuan penyerapan air oleh selulosa.

\subsection{Metode}

a. Preparasi selulosa

Tandan kosong kelapa sawit (TKKS) dicuci bersih dan dikeringkan dalam oven, lalu dipotong menjadi bagian yang lebih kecil. Pemurnian selulosa dilakukan dengan memanaskan TKKS dalam larutan $\mathrm{NaOH} \quad 12 \% \quad(\mathrm{~b} / \mathrm{v})$ selama 3 jam dengan suhu 90 $95^{\circ} \mathrm{C}$. Selulosa yang didapat selanjutnya diputihkan dengan memanaskan pada larutan Hidrogen Peroksida $\left(\mathrm{H}_{2} \mathrm{O}_{2}\right)$ pada suhu $90-95^{\circ} \mathrm{C}$ selama \pm 1 jam sampai serat berwarna putih bersih.

\section{b. Pengujian Daya Serap Air}

Sejumlah tertentu selulosa direndam dalam akuades pada suhu kamar selama 12 jam. Selanjutnya, selulosa ditiriskan dari akuades. Kemampuan selulosa mengabsorpsi air ( $\mathrm{H} 2 \mathrm{O})$ ditentukan dengan menimbang berat sampel setelah proses perendaman dan dihitung dengan persamaan: $\mathrm{mH}_{2} \mathrm{O}=(\mathrm{m} 2-\mathrm{m} 1) /$ $\mathrm{m} 1$ dimana $\mathrm{m} 1$ dan $\mathrm{m} 2$ adalah berat selulosa kering dan berat setelah absorpsi. Nilai $\mathrm{mH} 2 \mathrm{O}$ dihitung sebagai berat (gram) air per berat sampel (gram) ${ }^{(9)}$. Hal yang sama dilakukan terhadap popok sekali pakai pabrikan sebagai pembanding.

\section{HASIL DAN PEMBAHASAN}

Sebanyak 23\% dari hasil samping perkebunan kelapa sawit adalah TKKS. Banyak sekali potensi pemanfaatan selulosa tersebut yang salah satunya sebagai bahan SAP yang berbasis polimer alam.

Selulosa dari TKKS dapat dimurnikan melalui dua tahap proses, yaitu pemurnian dengan $\mathrm{NaOH}$ dan pemutihan dengan $\mathrm{H}_{2} \mathrm{O}_{2}$. Pemurnian dengan $\mathrm{NaOH}$ merupakan proses yang bertujuan melarutkan komponen lain dari TKKS selain selulosa. Melalui deliginifikasi diharapkan komponen seperti hemiselulosa, lignin, holoselulosa, dan komponen lain dapat larut. $\mathrm{NaOH}$ dipilih karena lignin lebih larut dalam kondisi alkali dan selulosa tidak!

Konsentrasi $\mathrm{NaOH}$ yang digunakan pada proses delignifikasi tidak boleh melebihi $17 \%$, karena selulosa akan mengalami perubahan struktur yang sangat berbeda dari aslinya pada konsentrasi $\mathrm{NaOH} 15-20 \%$. Selulosa yang didapat masih berwarna cokelat gelap, karena masih ada pigmen dan sisa lignin yang masih terikut dalam selulosa. Kemudian selulosa diputihkan dengan pemanasan dalam larutan $\mathrm{H}_{2} \mathrm{O}_{2}$ sampai berwarna putih bersih. Gambar 1 menunjukkan warna TKKS dalam larutan $\mathrm{NaOH}$. 


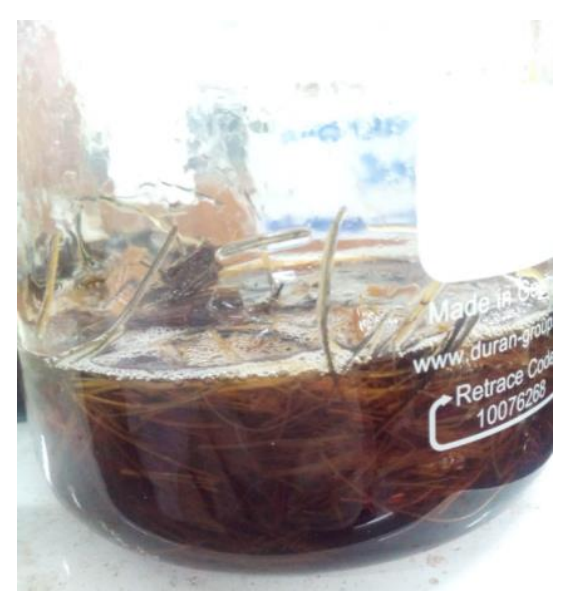

Gambar 1. TKKS yang sedang dimurnikan untuk menghilangkan pigmen dan sisa lignin

Setelah selesai pemutihan didapatkan selulosa yang berwarna putih bersih/cerah. Warna putih cerah tersebut menunjukkan bahwa pigmen serta lignin sudah larut, sehingga didapatkan selulosa dengan kemurnian tinggi.

Selulosa yang didapat kemudian dicuci bersih berulang-ulang menggunakan akuades hingga $\mathrm{pH}$ netral. Pemanasan dilakukan untuk menghilangkan sisa air yang masih tersisa dalam selulosa. Selulosa yang didapatkan setelah pemanasan dan pengeringan seperti ditunjukkan pada Gambar 2.

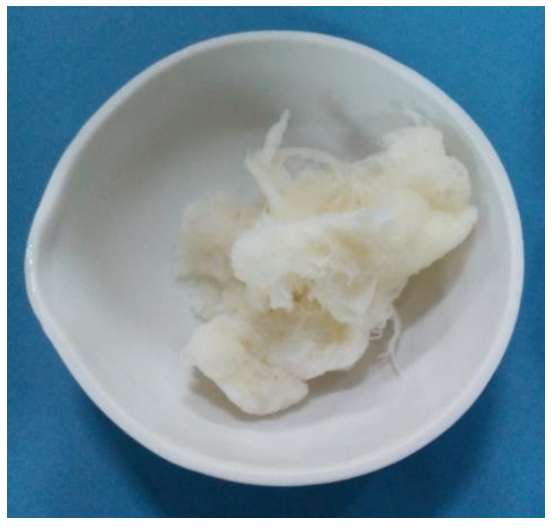

Gambar 2. Selulosa yang sudah putih bersih

Penentuan uji kapasitas absorpsi air merupakan salah satu parameter utama dari polimer, khususnya untuk pengujian suatu bahan kandidat sebagai absorben. Selulosa yang akan menjadi bahan baku 
SAP yang disintesis pada penelitian ini diuji kapasitas terhadap absorpsi air. Berat air yang mampu diserap oleh selulosa dibandingkan dengan

berat air yang diserap oleh bahan penyerap pada popok sekali pakai. Gambar 3 menunjukkan selulosa yang sedang diuji kemampuan absorpsinya terhadap air.

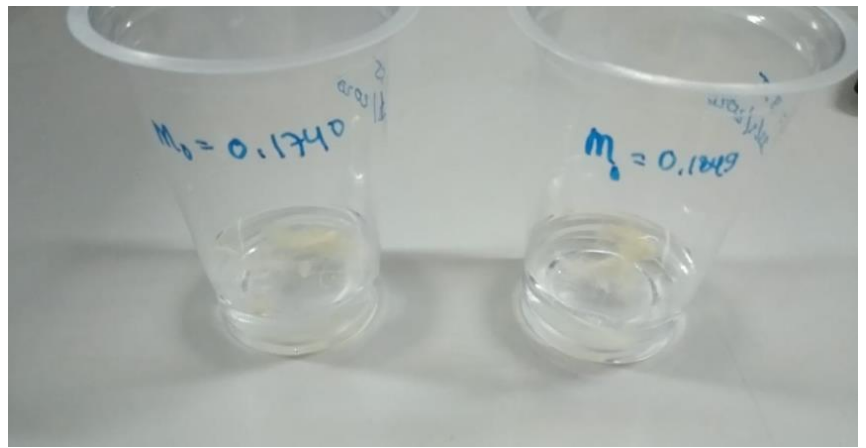

Gambar 3. Selulosa yang sedang diuji daya serapannya.

Berdasarkan hasil pengujian didapatkan daya serap selulosa terhadap air yang diukur tiap 4 jam selama 8 jam seperti terlihat pada Gambar 4. Dari Gambar 4 tersebut, terlihat bahwa pada jam ke-4 terjadi penyerapan air oleh selulosa dengan rata-rata
1,22345 gram atau sebesar 7 kali berat selulosa mula-mula.

Gambar 5 menunjukkan serapan air oleh gel popok sekali pakai, dimana penyerapan air rata-rata sebesar 100 kali berat serat sebelumnya.

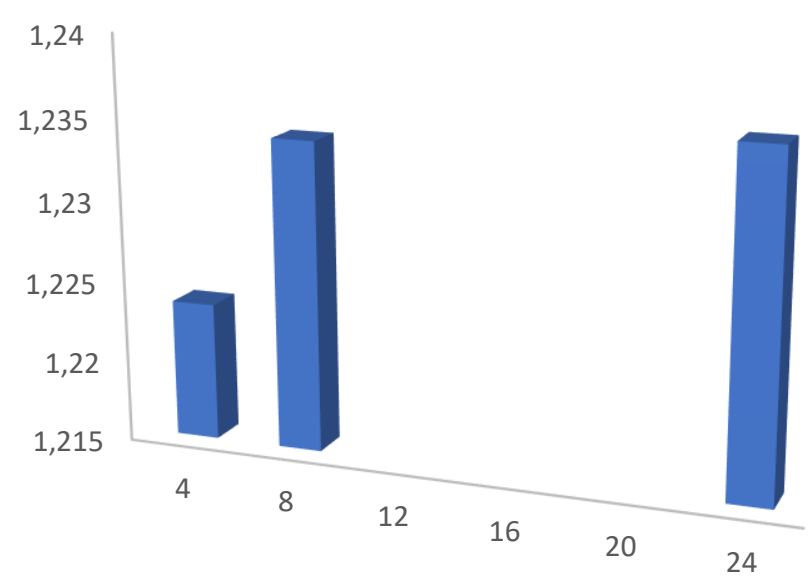

Gambar 4. Grafik penyerapan air oleh selulosa 


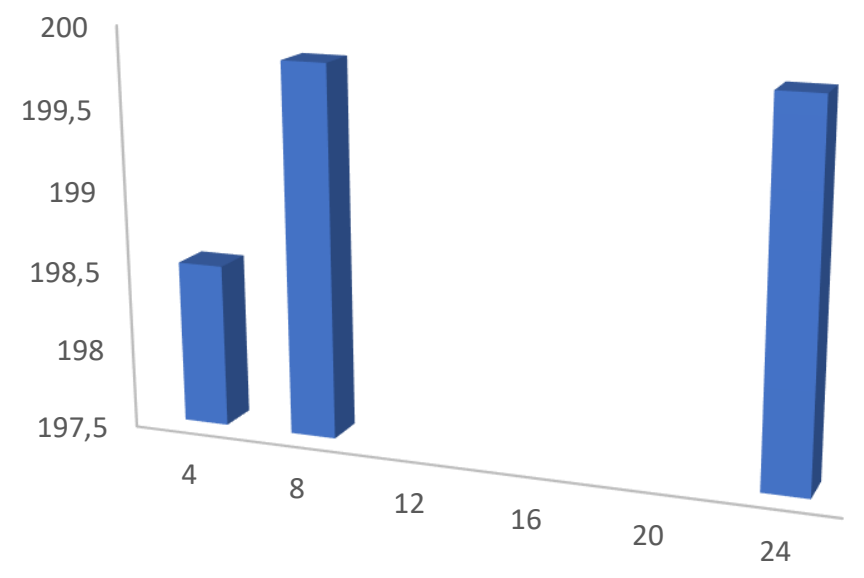

Gambar 5. Grafik penyerapan air oleh material diapers

Gel pada popok sekali pakai pada awalnya terlihat seperti serabut kapas. Setelah menyerap air, serat tersebut mengembang menjadi 100 kali berat awal. Material popok sekali pakai tersebut yang disebut dengan super absorbent polymer (SAP) sintetis yang memiliki kemampuan menyerap air dalam jumlah besar.

Selulosa TKKS sudah memiliki kemampuan menyerap air sebanyak 7 kali berat asal. Selulosa tersebut diharapkan bisa memiliki daya serap yang lebih besar ketika dilakukan proses polimerisasi. SAP dari pati dapat memiliki penyerapan tertinggi sebesar 241 kali dari berat semula.

\section{KESIMPULAN DAN SARAN}

Dari hasil pengujian, didapatkan bahwa selama 4 jam, selulosa mampu menyerap air sebanyak 7 kali berat selulosa awal, sedangkan untuk SAP memiliki kemampuan penyerapan hingga 200 kali berat asal. Kemampuan penyerapan air oleh selulosa masih kecil jika dibandingkan SAP. Hal ini karena selulosa masih memiliki rantai polimer yang cukup pendek, sehingga kemampuan penyerapannya belum maksimal. Proses polimerisasi selulosa diperlukan untuk meningkatkan kemampuan penyerapannya.

Penelitian lanjutan dengan proses polimerisasi terhadap selulosa menjadi SAP diharapkan dapat dilakukan untuk meningkatkan kemampuan penyerapannya, sehingga bisa menggantikan SAP sintesis.

\section{DAFTAR PUSTAKA}

Zohourian, M. M., \& Kabiri, K. (2008). Superabsorbent polymer materials: a review. Iranian Polymer Journal (English) 2008 , Volume 17 , Num ber 6; Page(s) 451 To 447.

Moelyaningrum, A. D. 2013. Persepsi Ibu Terhadap Sampah Popok Bayi Sekali Pakai Dan Manajemen Pengelolaanya. Prosiding Seminar Nasional Kependudukan," Peran Keilmuan Kesehatan Masyarakat dalam Pembangunan Kependudukan Pasca MDGs 2015", Jember 16 November 2013. Jember 
University Press. ISBN; 978-6029030-42-6

Ngadi, N., \& Lani, N. S. (2014). Extraction and Characterization of Cellulose Acetate from Empty Fruit Bunch (EFB) Fiber. Jurnal Teknologi, 35-36.

Dewanti, D. P. (2018). Potensi selulosa dari limbah tandan kosong kelapa sawit untuk bahan baku bioplastik ramah lingkungan. Jurnal Teknologi Lingkungan, 19(1), 8188.

Azizah, A., Irwan, A., \& Sunardi, S. (2016). Sintesis Dan Karakterisasi Polimer Superabsorben Berbasis Selulosa Dari Tanaman Purun Tikus (Eleocharis dulcis) TERCANGKOK AKRIL AMIDA (AAM). Jurnal Sains dan Terapan Kimia, 6(1), 59-70.

Laksanawati, T. A., Basuki, A., Ma'ruf, M., Trisanti, P. N., \& Sumarno, S. (2018, July). Synthesis and Characterization of Superabsorbent Polymer (SAP) based on Starch and Acrylic Acid. In Seminar Nasional Teknik Kimia Kejuangan (p. 17). 